Grand Valley State University

ScholarWorks@GVSU

1998

\title{
Environmental regulatory influence and product innovation: The contingency effects of organizational characteristics
}

Carol M. Sanchez

Grand Valley State University, sanchezc@gvsu.edu

William McKinley

Southern Illinois University Carbondale

Follow this and additional works at: https://scholarworks.gvsu.edu/mgt_articles

Part of the Business Administration, Management, and Operations Commons

\section{ScholarWorks Citation}

Sanchez, Carol M. and McKinley, William, "Environmental regulatory influence and product innovation: The contingency effects of organizational characteristics" (1998). Peer Reviewed Articles. 43.

https://scholarworks.gvsu.edu/mgt_articles/43

This Article is brought to you for free and open access by the Management Department at ScholarWorks@GVSU. It has been accepted for inclusion in Peer Reviewed Articles by an authorized administrator of ScholarWorks@GVSU.

For more information, please contact scholarworks@gvsu.edu. 


\section{ENVIRONMENTAL REGULATORY INFLUENCE AND PRODUCT INNOVATION: THE CONTINGENCY EFFECTS OF ORGANIZATIONAL CHARACTERISTICS}

CAROL M. SANCHEZ

Grand Valley State University

Department of Management

238 Lake Huron Hall

Allendale, MI 49401

Tel. 616/895-2543

SANCHEZC@GVSU.EDU

WILLIAM McKINLEY

Southern Illinois University at Carbondale

Department of Management

Carbondale, Illinois 62901-4627

Tel. 618/453-3307

DECLINE@SIU.EDU 
ENVIRONMENTAL REGULATORY INFLUENCE AND PRODUCT INNOVATION: THE CONTINGENCY EFFECTS OF ORGANIZATIONAL CHARACTERISTICS

\begin{abstract}
This paper examines the relationship between environmental regulatory influence and product innovation in a multi-industry sample of manufacturing organizations. Our theory argues that the influence of environmental regulation on the level of product innovation in a manufacturing organization is at least partially contingent on the organization's internal characteristics -- in particular, its structural flexibility and production process flexibility. Hypotheses are derived from our theory and tested, and the results are consistent with the conclusion that structural flexibility and production process flexibility moderate the environmental regulatory influence-product innovation relationship. Whether environmental regulation inhibits or promotes product innovation seems to depend at least in part on certain internal features of an organization. We discuss implications of our results for future organization studies research on environmental regulation, and for research on other types of external constraints on organizational performance.
\end{abstract}

KEYWORDS: environmental regulation, product innovation, flexibility, moderated regression. 
ENVIRONMENTAL REGULATORY INFLUENCE AND PRODUCT INNOVATION: THE CONTINGENCY EFFECTS OF ORGANIZATIONAL CHARACTERISTICS

Organizational innovation and technological advantage are crucial components of firmlevel survival (Dougherty, 1996; Lengnick-Hall, 1992). While innovation has always been a key aspect of competition in high-technology industries, it is important in most other industries as well (Clark, 1987). However, some business analysts argue that the innovativeness of U.S. firms is declining (e.g., Teece, 1987; Wheelwright, 1987). Part of this decline has been attributed to increasing regulation of corporations, particularly environmental regulation (see Breyer, 1982; Marcus, 1987). Environmental regulation is legislation that establishes standards designed to control the material and energy outputs of society to the biophysical environment (Cohen, 1987; Cook, 1988; Westman, 1985; Yandle, 1989). The argument for environmental regulation as a suppressor of innovation rests on the assumption that the deterministic nature of environmental laws limits firms' strategic choices, and constrains their ability to innovate (see Breyer, 1982). While this argument is taken for granted in some scholarly and management circles, relatively little large-sample empirical research has been devoted to testing it.

The purpose of this paper is to help fill that gap, and examine the conditions under which environmental regulation inhibits or contributes to organizational innovation. Such research is important because it enhances our knowledge about the consequences of environmental regulation for organizations. We make a theoretical argument that the effect of environmental regulation on a manufacturing organization's propensity to develop new product innovations depends on the organization's flexibility. We discuss two dimensions of flexibility -- structural flexibility and production process flexibility -- and argue that they are key 
variables that moderate the relationship between environmental regulation and product innovation. Two hypotheses are developed from this argument, and then tested with data drawn from a random sample of manufacturing plants spanning a number of different industries. The results support the general interpretation that structural flexibility and production process flexibility moderate the environmental regulatory influence-product innovation relationship. Thus, internal organizational characteristics seem to play a role in determining how innovative manufacturing organizations can be in response to environmental laws. These results are discussed in terms of their importance for organization studies, and directions for future research on the organizational effects of environmental regulation are identified.

\section{ENVIRONMENTAL REGULATION AND PRODUCT INNOVATION}

A relatively new and growing body of organization studies literature attempts to view environmental regulation from a strategic point of view, by examining the relationship between environmental regulation and organizational performance (Bartel \& Thomas, 1987; Dean \& Brown, 1995; Leonard, 1984; Marcus, 1988; Marcus \& Goodman, 1986; Shaffer, 1994). Although some studies suggest a positive relationship between environmental regulation and organizational performance (Leonard, 1984; Bartel \& Thomas, 1987), other studies imply a negative relationship (Birnbaum, 1984; U.S. Small Business Administration, 1975), while still others show no relationship at all (Chen \& Metcalf, 1980; Folger \& Nutt, 1975).

An important aspect of organizational performance is innovation, which we define as the adoption of a device, system, policy, program, process, product, or service that is new to the adopting organization (Damanpour, 1991; Collins, Hage, \& Hull, 1988). As is true for the literature on environmental regulation and organizational performance, existing literature 
contains inconsistent suggestions about the relationship between regulation and innovation. Opponents of regulation predict that the cost of complying with federal regulations will approach $47 \%$ of the federal bud get by 2000, up from $40 \%$ in 1988 (The Economist, 1996). They argue that regulatory constraints add sizable compliance costs to firms, forcing cutbacks in R\&D efforts and limiting innovative initiatives. Young (1982) found that drug regulation in the United States increased drug industry costs, drove much research overseas or into safer generic drugs, and slowed or blocked the introduction of new drugs, compared with drug introduction rates in Great Britain. A more intense regulatory environment in the United States is related to longer lags in new drug introductions, according to a later study (Yeoh, 1995).

More specifically, critics argue that environmental regulation undermines innovation, and that the bureaucracy required to comply with environmental regulation restricts firms from pursuing cutting-edge technology (Breyer, 1982). Managers of environmentally-regulated firms argue that it is harder to innovate because regulations often change unexpectedly, and because regulators are unpredictable (Birnbaum, 1984). This increased uncertainty motivates firms to de-emphasize risky strategies such as innovation (Birnbaum, 1984). The net effect of these constraints is reduced innovation, which many argue puts environmentally-regulated firms at a competitive disadvantage (Caves, 1982; Guttmann, Sierck, \& Friedland, 1992; Scherer \& Ross, 1990).

A competing argument is that environmental regulation, if viewed as an external jolt, can stimulate innovation within an organization (Marcus \& Weber, 1989; Meyer, 1982). In the absence of external jolts, existing organizational practices are often not challenged, and members may resist innovation, fearing it will change the status quo (Van de Ven, 1986). A 
jolt such as environmental regulation may appear disruptive and threatening to a firm, but it may be necessary to induce innovation (Schon, 1971).

Among the different kinds of innovation is product innovation, which refers to "a new technology or combination of technologies introduced commercially to meet a user or a market need" (Utterback \& Abernathy, 1975: 642). Given the necessity of adaptation to technical and market changes (Anderson \& Tushman, 1990; Dougherty, 1992a, 1992b; Henderson \& Clark, 1990; Schoonhoven, Eisenhardt, \& Lyman, 1990; Tushman \& Anderson, 1986), product innovation has an important potential role in organizational effectiveness. This is particularly true for manufacturing organizations, which are the focus of this study. Beyond the "jolting" effect of environmental regulation on innovation generally, we believe that environmental regulation has a specific effect on product innovation, mediated through transformations in production processes.

Environmental regulation often generates changes in production processes (Porter, 1991; U. S. Small Business Administration, 1975). Changes in production processes, in turn, can induce or result in new product innovations (Clark, 1988). For example, adopting new flexible manufacturing technologies allows companies to produce a wider range of products at costs that previously could only be achieved through mass production of a standardized output (Jones $\&$ Butler, 1988). An example of the positive effect of environmental regulation on product innovation is found in chemical manufacturing. Faced with the rapidly approaching deadline for the worldwide phaseout of chlorofluorocarbons (CFCs), Imperial Chemical Industries (ICI), Du Pont Co., and Elf Atochem developed the technology required to produce CFC substitutes in record time. Development time was reduced from the ind ustry norm of more than a decade to only five years (Weber, 1993). 
To summarize the discussion thus far, we have reviewed literature that suggests conflicting arguments about the effect of environmental regulation on innovation generally, and product innovation more specifically. One way to reconcile these arguments is to develop a contingency framework which proposes that the relationship between environmental regulation and product innovation varies as a function of the moderating effect of organizational flexibility. While there may be other moderators of the environmental regulation-product innovation relationship, we believe that organizational flexibility is a critical attribute determining the potential for translating regulatory influence into product innovation. Furthermore, the use of this moderator is consistent with the theoretical structure of past contingency theory models (e.g., Cheng \& McKinley, 1983; Drazin \& Van de Ven, 1985; Gresov, 1989; Schoonhoven, 1981). We propose that two dimensions of organizational flexibility -- structural flexibility and production process flexibility -- are important organization-level variables that determine the sign of the environmental regulation-product innovation relationship.

\section{Structural Flexibility}

Structural flexibility is defined here as the ability to change and reconfigure organizational structure quickly. Structural flexibility helps organizations adapt to changes in their competitive and regulatory environments, allowing them to maintain a responsive posture. Structural flexibility enhances internal cooperation and coordination via teams, task forces, and lateral information processing, all of which are necessary to accommodate changes in technology and products (Daft, 1994; Hayes \& Jaikumar, 1988). We propose that a manufacturing plant that has high structural flexibility will respond to environmental regulation 
with more new product innovations than a plant that is low in structural flexibility. This is because structural flexibility facilitates the modifications in production processes that are necessary to accommodate environmental regulation, and those changes open doors for the introduction of new products. In other words, structural flexibility plays a catalyst role, leading to a more positive relationship between environmental regulation and product innovation.

A proxy for structural flexibility is organizational age, with younger organizations being more structurally flexible, and older organizations more structurally inert (Hannan \& Freeman, 1984, 1989). Given our interest in manufacturing plants, we define age as the number of years since a plant was established. Based on the argument in the preceding paragraph, we expect that plant age will also be an important moderator of the relationship between environmental regulation and product innovation. As plants get older, structural inertia increases and the level of structural flexibility decreases. The interests of the organization's members become entrenched, and their sensitivity to the need to respond to environmental change is reduced. This is particularly true if older plants have long-tenured employees, as employees with long tenure are more resistant to change (Hall, 1991: 185). Despite the prevalence of organizational downsizing and restructuring throughout the history of American manufacturing, it is reasonable to expect a positive correlation between plant age and the tenure of plant employees. Thus, given the onset of an external event such as environmental regulation, older plants will have less tendency to modify their production processes quickly, and more inertial barriers to introducing new products when processes are modified. Consistent with this, Van de Ven (1986) argued that older organizations are more likely to have a large number of entrenched structures and systems that will discourage innovation. Tyre and Orlikowski (1994) found that change in a new production technology was greatest immediately after the 
technology had been introduced, and that adaptation leading to innovation decreased as time went on. All these arguments suggest the following hypothesis:

\section{Hypothesis 1: The older a plant, the more negative the relationship between environmental regulation and product innovation.}

This hypothesis posits that the slope of the environmental regulation-product innovation relationship will move in a negative direction with increasing plant age. For example, if the environmental regulation - product innovation slope is positive at the "young" end of the age continuum, the hypothesis predicts that the slope will become less positive or even negative in older plants. If the slope is negative at the "young" end of the age continuum, the hypothesis would be confirmed if the slope became more negative in older plants. As is clear from these examples, the hypothesis is confined to a prediction about the direction of the moderating effect of plant age.

Production Process Flexibility

Aside from the effects of structural flexibility on manufacturing, production process modifications can be generated in other ways. Today, for example, new manufacturing technology is redefining the industrial landscape. Traditional mass production allowed plants to produce large quantities of one product at low unit costs, or smaller quantities of several products at higher unit costs. As a result, greater efficiency led to increased manufacturing rigidity, or the "productivity paradox" (Skinner, 1986). But the development of computerintegrated, flexible production systems permits firms to produce a wide range of products at low unit costs, breaking the "productivity paradox" (Pitts \& Lei, 1996). Flexible manufacturing systems (FMS) are based on the computer redefinition of production processes and the creation of a factory-based information system. Tools and dies required to manufacture 
different, customized products are changed automatically by electronically entering the change orders into computers that drive the FMS.

Factories using FMS avoid costly delays previously associated with product changeovers, and increase their ability to customize production. Customization is the extent to which a product is produced according to customer specifications, and it is an important indicator of production process flexibility. We therefore suggest that the level of customization in a plant's production system will positively moderate the relationship between environmental regulation and product innovation. Firms with a high level of customization have already made investments to maintain the flexibility of the production process (Meredith, 1987; Nemetz \& Fry, 1988), so that when environmental regulations are imposed, the necessary modifications in the production process (Barrett, 1991) are easier. Those modifications then increase the possibilities for introducing new products. Thus, a firm that produces customized products is likely to find that environmental regulation is a greater force for product innovation than would be true in a firm that produces standardized products. This suggests the following hypothesis:

\section{Hypothesis 2: The more a plant is oriented toward customized production, the more positive the relationship between environmental regulation and product innovation.}

This hypothesis proposes that the slope of the environmental regulation-product innovation relationship will move in a positive direction as the degree of customized production increases. Like Hypothesis 1, Hypothesis 2 is confined to a prediction about a moderating effect, and makes no inference about the sign of the regulation-innovation slope at the "standardized" end of the customization continuum.

METHOD 
Sample

Data were collected from a random sample of 331 New Jersey manufacturing plants employing 200 or more people (Blau, Falbe, McKinley, \& Tracy, 1976; McKinley, 1987). One hundred and ten plants agreed to participate in the study, for a response rate of $33 \%$. These 110 plants are representative of manufacturing firms in general for two reasons. First, the 110 participating plants did not differ significantly from the sample of 331 in terms of size (number of employees), product type (two-digit SIC code), or whether the plant was a single-site company or a branch of a larger firm. Second, the 331 plants in the larger sample were randomly selected from manufacturing establishments in a state whose establishments encompass all two-digit Stand ard Industrial Classification (SIC) codes for manufacturing. These results suggest that the 110 plants are a fair approximation of the range of manufacturing in the United States.

Data were gathered in each of the 110 plants using a structured questionnaire administered to senior managers during an interview that sometimes lasted several hours. The senior managers included the plant manager, the head of production, and the personnel manager. All information pertained to organizational characteristics, rather than characteristics of the plant's employees. Data were collected on the structural and technological attributes of the plant, such as size, personnel distributions, production technology, and automation of production equipment (Blau et al., 1976; McKinley, 1987). In a total of 89 plants, interviews were conducted by a team of two interviewers. In the remaining 21 plants, the interviews were conducted by a single interviewer. Consensus was high among the interviewers who operated in teams, because the vast majority of the variables were item counts, and did not require interviewer judgment. In cases where disagreements about variable coding did occur, they 
were resolved by discussion among the interview team members. The presence of at least one interviewer at all of the 110 plants guaranteed that the responses were actually made by the plants' senior managers.

The mean number of employees in the 110 plants was 497 in 1973, but more than half of the plants had fewer than 360 employees. Personnel totals ranged from less than 100 to more than 4,000 with a standard deviation of 553, indicating a highly skewed distribution. Ninety-nine of the 110 plants had a parent company, and some information was collected on the larger corporate structure. However, corporate information was kept separate from the plant data, even when the plant was located at corporate headquarters. Secondary data were also obtained from published reports of the U.S. Bureau of the Census, and those data were used to develop a measure of the impact of environmental regulation.

Measures

Dependent variable. The dependent variable is a measure of product innovation (NEWPROD2). The measure is the number of new products introduced in 1973 and the previous four years, divided by the total number of full-time plant personnel in 1973. Dividing by the number of personnel standardizes the number of new products for the scale of operations, which is important for any measure based on the quantity of an item. We also multiplied the ratio by 100 , so that the final measure was the number of new products introduced per 100 employees.

Independent variable. The independent variable is environmental regulatory impact (REGNJ73B), specifically the impact of the federal Clean Air Act of 1970. The Clean Air Act of 1970 was a very significant piece of environmental legislation. For the first time, national ambient air quality standards (NAAQS) were set for stationary sources, including 
manufacturing plants, to be achieved by 1975 (Davies \& Davies, 1980). To meet this deadline, plant managers and other executives would have had to begin to plan for capital investments and adaptation activities immed iately after the passage of the Act in 1970. This adaptation period overlaps with the time period in which the dependent variable, product innovation, was measured.

One result of the Clean Air Act would be capital expenditures for air pollution abatement. Therefore, a proxy measure of the post-1970 impact of the Clean Air Act of 1970 was developed: the ratio of capital expenditures for air pollution abatement in 1973 to total capital expenditures in 1973. It is reasonable to use 1973 capital expenditures as the measure of post-1970 regulatory impact because the Clean Air Act of 1970 contained strict and complex time requirements for compliance. These requirements compelled some manufacturers to petition the EPA for a one-year suspension of certain standards arguing that emission control technology was not available (Davies \& Davies, 1980). Because deliberations of this type took place, we argue that a lag time of at least two years was required to plan, design, and implement technology responses like the purchase of pollution abatement equipment that would be reflected in records of expenditures. Our proxy measure thus captures the results of a planning and adaptation process that was reflected in financial statements at the same time the new products counted in the dependent variable were being introduced. The pollution abatement expenditures measure therefore serves to test the differences in the environmental regulatory impact-product innovation relationship being predicted in our hypotheses.

The environmental regulatory impact ratio was computed at the industry level of analysis, with a different score for each ind ustry (SIC code) that was represented in the data set (see Table 1). The data for this measure were obtained from the 1973 annual reports entitled 
Pollution Abatement Costs and Expenditures and Census of Manufactures, both published by the U.S. Bureau of the Census. Our measure of environmental regulatory impact resembles the measures used by other scholars in recent studies of environmental regulation. In these studies, regulatory intensity or impact was measured by dividing a figure representing an expenditure or an emissions reduction required by an environmental regulation, by a figure that controls for the magnitude or size of the unit of analysis (Dean \& Brown, 1995; Sánchez, 1995).

Insert Table 1 about here

Although the manufacturing data were collected 23 years ago, for the particular relationship we are concerned with in this paper, we believe that the age of the data does not represent a problem. We argue that the relationship between environmental regulatory impact and product innovation is relatively uniform, no matter in what era measures of the independent variable and dependent variable are taken. This is because environmental regulation will always have an influence on the manufacturing processes of production facilities, causing changes in production processes that open up the possibility of new product introductions.

This will be true whether regulation is of the command-and-control type typical of the 1970s, or the standard-setting type that is becoming more common in the 1990s. Although certain approaches to environmental regulation have changed since the 1970s, the fundamental nature of environmental regulation and the way firms view it has not altered significantly during the past two decades. Even the most flexible of environmental laws -- the Clean Air Act Amendments of 1990 -- mirrors earlier versions of the Clean Air Act (Portney, 1990; Yandle, 1989). Just as in 1970, the 1990 Clean Air Act Amendments require operating permits, subject 
violators to enforcement provisions, impose reporting burdens and operational delays, and force firms to rely on state implementation plans. Command-and-control approaches have not been completely eliminated from more recent environmental rules, and firms that are greatly affected by them view current environmental laws as a moving target that carries as much uncertainty as the 1970s legislation (Sánchez, 1995).

If anything, it could be argued that the newer, standard-setting environmental rules have more potential for changing individual production processes than 1970s-style command-andcontrol regulation. Environmental laws that set standards for compliance instead of mandating technologies will provide a greater number and variety of production process options to firms, creating space for new product innovation. Therefore, this study may actually be a conservative test of the environmental regulatory impact-product innovation relationship because it uses 1970s data. Had we been able to use 1990s data, we might have expected even stronger relationships than we are likely to obtain with the 1970s data, given the leeway for innovation provided by the new wave of environmental rules during the post-1970s period.

Moderator variables. Plant age (AGE73) was measured by subtracting the year in which the plant was established from 1973. The oldest plant was 141 years old, the youngest plant was four years old, and the mean age was 37 years.

Customization (CUSTOM) was measured by the percentage of plant sales falling into the category of production according to customer specifications, plus the percentage of sales falling into the category of standardized production modified to customer specifications. The mean score on this variable was $39.68 \%$.

Control variables. The natural logarithm of the number of employees in the parent company (LOGCOSZ), and the number of different product lines produced in 1972 (PROD) 
were used as control variables. The log transformation of the first control variable was implemented to deal with the problem of skewness. In addition, we included a third control variable that measured the adaptability of the plant's production equipment, i.e., whether the equipment was of limited or varied use and sequence (ADAPT).

Analysis

The hypotheses predict that there will be moderating effects of plant age and customization on the slope of the relationship between environmental regulatory impact and product innovation. For this reason, moderated regression analysis was chosen as the appropriate technique to test the hypotheses. In moderated regression, a dependent variable is regressed on an independent variable, a moderator variable, and a cross-product term between the independent and the moderator variables (McKinley, 1987). This procedure partials the main effects of the independent and moderator variables from their cross-product (Cohen \& Cohen, 1975: 295). Under these conditions, a statistically significant regression coefficient for the cross-product term provides evidence that the slope of the relationship between the independent and dependent variables changes across levels of the moderator variable (Cohen \& Cohen, 1975: 306). The important test statistic for evaluating a moderating effects hypothesis is the cross-product term from which the linear effects of the predictor and moderator variables have been partialled, and not the significance of the overall regression equation (Bedeian \& Mossholder, 1994). However, we will also report the latter statistic.

The sign of the regression coefficient for the cross-product term indicates the direction of the change in slope as the moderator variable increases. For example, a positive sign for a cross-product term regression coefficient would mean that the independent-dependent slope moves in a positive direction as the moderator variable increases. Our first hypothesis predicts 
a negative moderating effect, which would be represented by a significant, negative regression coefficient for the cross-product term between environmental regulatory impact and plant age. The second hypothesis predicts a positive moderating effect, which would be represented by a significant, positive regression coefficient for the cross-product term between environmental regulatory impact and customization.

Moderated regression analysis can also be used to produce a "family" of linear equations (Cohen \& Cohen, 1975: 313), each member of which shows the relationship between the independent and the dependent variable at a different level of the moderator variable. High, medium, and low values of the moderator variable can be substituted into a moderated regression equation, and the resulting linear equations can be graphed. In this way, the difference in the independent-dependent slope at different levels of the moderator variable can be clearly seen.

Descriptive statistics and zero-order correlations for the study variables are presented in Tables 2 and 3.

Insert Tables 2 and 3 about here

\section{RESULTS}

The results of the moderated regression analyses are displayed in Tables 4 and 5. Equation (1) in Table 4 shows the main effects of environmental regulatory impact and the moderating variable, plant age, on product innovation (rows 4 and 5). Equation (2) in Table 4 adds the cross-product term between environmental regulatory impact and plant age. As shown in Row 6, the regression coefficient for the cross-product term is positive and significant $(B=$ 
$.413, \mathrm{p} £ .05$, two-tailed). In addition, the $\mathrm{R}^{2}$ increase associated with the entry of the crossproduct term is .041 . Taken together, the results support the idea that plant age moderates the slope of the relationship between environmental regulatory impact and product innovation, although the findings are not consistent with the negative moderating effect predicted by Hypothesis 1. Surprisingly, the results indicate that the slope of the environmental regulatory impact-product innovation relationship moves in a positive direction as plant age increases.

The results of the F-test for the overall equation were also significant $(\mathrm{F}=2.04$, $\mathrm{p} £$.10). Recall, however, that a significant $\mathrm{F}$ for a regression equation is not required to validate the significance of a moderating effect (Baron \& Kenny, 1986; Bedeian \& Mossholder, 1994).

Insert Table 4 about here

In Table 5, Equation (1) shows the main effects of environmental regulatory impact and the second moderating variable, customization, on product innovation (rows 4 and 5). Equation (2) reflects the addition of the cross-product term between environmental regulatory impact and customization. Row 6 shows that the regression coefficient for the cross-product term is positive and significant $(\beta=.280, \mathrm{p} £ .05$, one-tailed $)$. The use of a one-tailed test of statistical significance is appropriate here because the sign of the regression coefficient is consistent with the prediction of Hypothesis 2. With the addition of the cross-product term, the $\mathrm{R}^{2}$ increases by .032. In summary, these results support Hypothesis 2, which states that customization will have a positive moderating effect on the slope of the relationship between environmental regulatory impact and product innovation. 
The F-test of the overall regression equation yields the same results as for Equation 2 of Table $4(\mathrm{~F}=2.04, \mathrm{p} £ .10)$.

Insert Table 5 about here

Table 6 presents two sets of linear equations derived from the moderated regression equations (i.e., equation 2 in Table 4 and equation 2 in Table 5). The linear equations in Table 6 were generated by first substituting the means of the control variables into the appropriate moderated regression equation. This resulted in the consolidation of the control variables into the y-intercept, producing two "reduced" equations of the form:

$$
y=a+b x+c z+d(x * z) .
$$

Next, different values of the moderating variable (z) were substituted into each reduced equation. The outcome was a set of three linear equations showing the relationship between environmental regulatory impact and product innovation at different levels of plant age, and another set of three linear equations showing the relationship between environmental regulatory impact and product innovation at different levels of customization. By comparing the slope coefficients of these equations, one can get a clear picture of how the slope changes as the moderator variable increases. The sets of linear equations can also be graphed to show how the slope of the relationship changes across different levels of plant age and customization (McKinley, 1987).

Insert Table 6 about here 
Table 6 shows that for older plants (one standard deviation above the average score for plant age), the slope of the relationship between environmental regulatory impact and product innovation is positive $(b=.0976)$. These results suggest that older plants, not younger ones, translate high environmental regulatory influence into higher product innovation. In younger plants (one standard deviation below the average score for age), the slope of the environmental regulatory impact-product innovation relationship is negative $(b=-.0939)$. Therefore, young plants appear to be inhibited in generating new products in response to high environmental regulatory impact. The linear equations in Table 6 confirm the inference about slope change made from the sign of the cross-product term regression coefficient in Table 4 . Figure 1 displays graphs of the linear equations in Table 6, showing the moderating effect of plant age on the environmental regulatory impact-product innovation slope.

Insert Figure 1 about here

Table 6 also demonstrates that for plants with a relatively low level of customization (one standard deviation below the average customization score), the slope of the relationship between environmental regulatory impact and product innovation is negative $(b=-.0905)$. For plants with less customized production, being situated in an industry heavily impacted by the 1970 Clean Air Act tends to reduce product innovation. For plants with highly customized production, on the other hand, the slope of the environmental regulatory impact-product innovation relationship is positive $(\mathrm{b}=.1040)$. For those plants, location in an industry heavily influenced by the 1970 Clean Air Act tends to be favorable for product innovation. The linear equations shown in the bottom half of Table 6 are consistent with Hypothesis 2 and with the 
sign of the cross-product term regression coefficient in Table 5. This second set of linear equations is graphed in Figure 2.

Insert Figure 2 about here

In summary, the results of this study suggest that environmental regulation may inhibit or contribute to product innovation, depending on characteristics of the plants that are the sites of new product introductions. Two of the plant characteristics that may make a difference are plant age and the degree to which plant production is customized or standardized. While the results of this study should be interpreted with caution, they do point to the potential value of future research to explore the effects of environmental regulation from a contingency perspective.

\section{DISCUSSION}

This study is rooted in the tradition of contingency theory (e.g., Cheng \& McKinley, 1983; Drazin \& Van de Ven, 1985), but it extends that tradition into new theoretical and empirical territory. As noted at the beginning of this paper, there has been little empirical research examining the influence of environmental regulation on organizational innovation, and almost none conducted with attention to possible moderating effects. The results of this paper suggest that the effects of moderating variables on linear relationships are interesting and merit serious exploration. It is also worth mentioning that the interactions among moderating variables often create higher-order effects, similar to the "gestalts" discussed by Miller (1987; Miller \& Friesen, 1984). That is, organizations will demonstrate complex interactions as their structural and internal variables, such as age and the degree of customization, interact with 
relationships like that between environmental regulation and product innovation. Further, the way these complex interactions are configured may be predicted and interpreted as organizational gestalts (Miller, 1987). Understanding how these moderating effects operate is beneficial for the development of more refined theory in this area.

The results of this study suggest that old plant age and an orientation toward customized production both enhance the tendency of a plant to respond to environmental regulatory influence by introducing new products. It is relatively clear why customization, as a proxy for production process flexibility, should magnify the likelihood of new product introduction when the external environment is changed by "green" legislation. A manufacturing plant that is set up to produce products according to customer specifications has already made a commitment to modifying the production process repeatedly to meet customers' needs. Thus, as external shocks such as environmental regulation make new demands on these plants, they can change their production processes more flexibly, and initiate new product designs to match the revised processes.

However, it is less clear why plant age also has a positive moderating effect on the relationship between environmental regulatory influence and product innovation. We had predicted that plant age, as a proxy for low structural flexibility, would have a negative moderating effect on this relationship. However, the findings (at a two-tailed level of statistical significance) indicated exactly the opposite. One interpretation of this counterintuitive result is that older plants may be more structurally inert (Hannan \& Freeman, 1984, 1989), but may also exhibit high flexibility along dimensions other than organizational structure. One such dimension may be the flexibility of the workforce. Upton (1995) found that workforce experience was positively related to flexibility, where flexibility was defined as the range of 
products a plant can produce. If older plants have more experienced workforces than younger plants, and this experience allows the workers to be adaptable in introducing new products, this effect could overwhelm any negative moderating effect due to age-induced structural inertia. The result would be what we see in our data: a positive moderating effect of plant age on the slope of the environmental regulatory influence-product innovation relationship. This interpretation is interesting because it suggests that there are many possible dimensions of flexibility -- certainly more than the two we identified in our theoretical discussion above. Plant age may tap at least two of these dimensions: a structural flexibility dimension that varies inversely with age, and a workforce flexibility dimension that varies directly (positively) with age.

A second, and related, interpretation is that older plants have routinized the procedures necessary to change manufacturing processes, which would facilitate the introduction of new products when those plants are affected by "green" legislation. While this argument may seem counter to received wisdom about organizational age, it is likely that production process modification becomes easier with repeated experience at such modification. This is consistent with Greenwood and Hinings' (1996) statement that experience increases capacity for action. Older, surviving plants have had to make many more process transformations in their lifetimes than their younger counterparts. This raises the probability that they will make other similar changes in the future (Amburgey, Kelly, \& Barnett, 1993), and helps standardize the phenomenon of change. The structural inertia that is associated with organizational age (Hannan \& Freeman, 1984, 1989) is not necessarily incompatible with this hypothesized effect. Structural inertia increases the day-to-day predictability of the division of labor and the chain of command, thus providing a stable and certain context within which flexible technological 
adaptation can take place. This would help explain Tyre and Orlikowski's (1994) report of later episodes of adaptation in production technologies that follow the initial burst of postintroduction adaptation.

A third, and related, explanation of the positive effect of plant age on the environmental regulation - product innovation relationship is that older plants may be staffed with employees having longer tenure, and those employees may have a greater stake in the survival of the organization. They will be thus more willing to take the personal risks associated with innovation.

In contrast, younger plants may be less adept at technological adaptation, because new organizations need time to acquire workforce experience, and to learn roles, rules, and routines that make technical change easier. Employees of younger plants may also have shorter tenure and thus possess a weaker commitment to the survival of the organization. This may make them less willing to initiate what could be risky innovative behavior. Therefore, the young plants in our sample may experience barriers to new product introduction, accounting for the negative environmental regulatory influence-product innovation slope at the "young" end of the age continuum (Figure 1). Time and patience are required for a new organization to incorporate work patterns that are flexible and responsive to changing conditions. Until that has occurred, new organizations tend to adopt generalized skills produced outside the organization -- skills whose lack of uniqueness allows the organization very little flexibility (Stinchcombe, 1965).

\section{IMPLICATIONS AND DIRECTIONS FOR FUTURE RESEARCH}


The results of this study suggest a number of directions for future research. First, we emphasize that our findings are based on responses to one piece of "green" regulation (the Clean Air Act of 1970), and are specific to one particular kind of organization (manufacturing plants). Thus, an important agenda for future empirical investigation is to replicate the analysis reported here, using other types of environmental regulation. While many aspects of the Clean Air Act of 1970 are common to environmental laws passed since then (Portney, 1990), there is no necessary sharing of all relevant properties across all types of environmental regulation. Replication could show how generalizable our results are to environmental legislation passed since 1970. Replications could also be extended to other types of organizations and other kinds of innovation (for example, process innovation). The overall goal would be to use this study as the starting point for a theoretical and empirical generalization process that would expand our contingency model into new domains.

Assuming our results do have generalizability, it should be possible to construct innovation profiles for various kinds of organizations impacted by environmental regulation. Our findings suggest that the environmentally regulated organizations most likely to implement innovations will be those that are older and oriented toward producing to customer specifications. In contrast, the environmentally regulated organizations least likely to introduce innovations will be young and oriented toward standardized production. These innovation profiles are consistent with Figures 1 and 2, but would need to be verified by a stream of additional research. From a practical perspective, the outcome of such a research stream would be a much better capacity to predict the situations in which environmental legislation will be a stimulus for innovation. 
Juxtaposing our paper with work like Upton (1995) also suggests the need for a great deal more research on the construct of flexibility. Flexibility is a favorite term among managers, consultants, and academics today (e.g., Volberda, 1996; Smith \& Zeithaml, 1996), and it is sometimes used to justify radical organizational restructuring programs involving the elimination of thousands of jobs. However, little theoretical or empirical effort has been devoted to defining the boundaries of the flexibility construct. This paper raises the possibility that flexibility is multifaceted, and that one can meaningfully conceive of variation in flexibility along a number of dimensions: structural, technological, strategic, and so on. Some of these dimensions may be orthogonal to one another: for example, technological flexibility may flourish best where structures are relatively inflexible, and therefore reproducible on a day-today basis. This orthogonality could be a rich source of theoretical development, particularly if applied to flexibility's role as a moderator of the relationship between regulatory constraints and organizational performance outcomes.

Finally, it would be profitable to integrate this paper with other work that is currently exploring the effects of external forces on organizations' performance, including the level of innovation. Environmental regulation is an important external variable that affects the activities of organizations, and it may be that it parallels the effects of other variables outside the organization. For example, Sánchez and McKinley (1995) conceptualized product regulation as an external influence on an organization's global competitiveness, and developed a theoretical model that predicted when product regulation is likely to positively or negatively affect global competitiveness. Correspondingly, Mone, McKinley, and Barker (1997) have followed an established stream of research (e.g., Cameron, Kim, \& Whetten, 1987; Whetten, 1980) in describing organizational decline as a critical external contingency that organizations 
must often deal with. Mone et al. (1997) have discussed moderating variables that determine when organizational decline inhibits or stimulates innovation. While organizational decline is clearly not identical to environmental or product regulations, all these phenomena share the attribute of shaping an organization's behavior toward certain outcomes and away from others. Integrating this paper with other like-minded research -- of which the work cited is only an example -- could eventually result in a general theory of external regulatory influence, conceiving regulation more broadly than a purely legal construct. Such a theory would relate the multiple aspects of external "regulation" to the multiple dimensions of internal organizational performance, with attention to the moderating variables that condition these relationships. While we are very far from such a theory at the present time, it is a worthy focus for future theoretical and empirical investigation. 


\section{ACKNOWLEDGMENTS}

Earlier versions of this paper were presented at the International Conference on

Environment, Energy, and Society, Carbondale, IL, 1994, and the Midwest Academy of Management, St. Louis, MO, 1995. The authors would like to thank the anonymous conference reviewers, as well as Michael Badawy and the JET-M referees, for their helpful comments on previous drafts of this paper. Both authors contributed equally to the paper. 


\section{REFERENCES}

Amburgey, T.L., Kelly, D., \& Barnett, W.P. 1993. Resetting the clock: The dynamics of organizational change and failure. Administrative Science Quarterly, 38: 51-73.

Anderson, P., \& Tushman, M.L. 1990. Technological discontinuities and dominant designs: A cyclical model of technological change. Administrative Science Quarterly, 35: 604633.

Baron, R.M., \& Kenny, D.A. 1986. The moderator-mediator variable distinction in social psychological research: Conceptual, strategic, and statistical considerations. Journal of Personality and Social Psychology, 51: 1173-1182.

Barrett, S. 1991. Environmental regulation for competitive advantage. Business Strategy Review (Spring): 1-15.

Bartel, A.P., \& Thomas, L.G. 1987. Predation through regulation: The wage and profit effects of the Occupational Safety and Health Administration and the Environmental Protection Agency. Journal of Law and Economics, 30: 239-259.

Bedeian, A.G., \& Mossholder, K.W. 1994. Simple question, not so simple answer: Interpreting interaction terms in moderated multiple regression. Journal of Management, 20: $159-165$.

Birnbaum, P.H. 1984. The choice of strategic alternatives under increasing regulation in high technology companies. Academy of Management Journal, 27: 489-510.

Blau, P.M., Falbe, C.M., McKinley, W., \& Tracy, P.K. 1976. Technology and organization in manufacturing. Administrative Science Quarterly, 21: 20-40.

Breyer, S. 1982. Regulation and its reform. Cambridge: Harvard University Press.

Cameron, K.S., Kim, M.U., \& Whetten, D.A. 1987. Organizational effects of decline and turbulence. Administrative Science Quarterly, 32: 222-240.

Caves, R. 1982. American industry: Structure, conduct, performance. Englewood Cliffs, N.J.: Prentice-Hall.

Chen, K.H., \& Metcalf, R.W. 1980. The relationship between pollution control record and financial indicators revisited. Accounting Review, 55: 168-177.

Cheng, J.L.C., \& McKinley, W. 1983. Toward an integration of organization research and practice: A contingency study of bureaucratic control and performance in scientific settings. Administrative Science Quarterly, 28: 85-100. 
Clark, K. 1987. Investment in new technology and competitive advantage. In D.J. Teece (Ed.), The competitive challenge: Strategies for industrial innovation and renewal: 59-82. Cambridge, MA: Ballinger.

Clark, K. 1988. Managing technology in international competition: The case of product development in response to foreign entry. In M.A. Spence \& H. Hazard (Eds.), International competitiveness: 27-74. Cambridge, MA: Ballinger.

Cohen, I. 1987. Regulation and deregulation. California Management Review, 29(4): 169183.

Cohen, J., \& Cohen, P. 1975. Applied multiple regression/correlation analysis for the behavioral sciences. Hillsdale, NJ: Lawrence Erlbaum.

Collins, P.D., Hage, J., \& Hull, F.M. 1988. Organizational and technological predictors of change in automaticity. Academy of Management Journal, 31: 512-543.

Cook, B.J. 1988. Bureaucratic politics and regulatory reform: The EPA and emissions trading. New York: Greenwood Press.

Daft, R.L. 1994. Management. Fort Worth, TX: The Dryden Press.

Damanpour, F. 1991. Organizational innovation: A meta-analysis of effects of determinants and moderators. Academy of Management Journal, 34: 555-590.

Davies, J.C. III, \& Davies, B.S. 1980. The politics of pollution. Indianapolis, IN: BobbsMerrill Company.

Dean, T.J., \& Brown, R.L. 1995. Pollution regulation as a barrier to new firm entry: Initial evidence and implications for future research. Academy of Management Journal, 38: 288303.

Dougherty, D. 1992a. Interpretive barriers to successful product innovation in large firms. Organization Science, 3: 179-202.

Dougherty, D. 1992b. A practice-centered model of organizational renewal through product innovation. Strategic Management Journal, 13: 77-92.

Dougherty, D. 1996. Organizing for innovation. In S.R. Clegg, C. Hardy, \& W.R. Nord (Eds.), Handbook of organization studies: 424-439. London: Sage Publications, Ltd.

Drazin, R., \& Van de Ven, A.H. 1985. Alternative forms of fit in contingency theory. Administrative Science Quarterly, 30: 514-539. 
The Economist. 1996. Over-regulating America: Tomorrow's economic argument (July 27): 19-21.

Folger, H.R., \& Nutt, F. 1975. A note on social responsibility and stock valuation. Academy of Management Journal, 18: 155-160.

Greenwood, R., \& Hinings, C.R. 1996. Understanding radical organizational change: Bringing together the old and the new institutionalism. Academy of Management Review, 21: 1022-1054.

Gresov, C. 1989. Exploring fit and misfit with multiple contingencies. Administrative Science Quarterly, 34: 431-452.

Guttmann, J.S., Sierck, A.W., \& Friedland, D.M. 1992. The new Clean Air Act's big squeeze on America's manufacturing base. Business Horizons, 35(2): 37-40.

Hall, R.H. 1991. Organizations: Structures, processes, \& outcomes. Englewood Cliffs, NJ: Prentice Hall.

Hannan, M.T., \& Freeman, J. 1984. Structural inertia and organizational change. American Sociological Review, 49: 149-164.

Hannan, M.T., \& Freeman, J. 1989. Organizational ecology. Cambridge, MA: Harvard University Press.

Hayes, R.H., \& Jaikumar, R. 1988. Manufacturing's crisis: New technologies, obsolete organizations. Harvard Business Review (September-October): 77-85.

Henderson, R.M., \& Clark, K.B. 1990. Architectural innovation: The reconfiguration of existing product technologies and the failure of established firms. Administrative Science Quarterly, 35: 9-30.

Jones, G.R., \& Butler, J.E. 1988. Costs, revenue, and business level strategy. Academy of Management Review, 13: 202-213.

Lengnick-Hall, C.A. 1992. Innovation and competitive advantage: What we know and what we need to learn. Journal of Management, 18: 399-429.

Leonard, H.J. 1984. Are environmental regulations driving U.S. industry overseas? Washington, DC: The Conservation Foundation.

Marcus, A.A. 1987. U.S. firms' responses to regulation: Stonewalling and opportunism. Long Range Planning, 20(3): 98-104. 
Marcus, A.A. 1988. Responses to externally induced innovation: Their effects on organizational performance. Strategic Management Journal, 9: 387-402.

Marcus, A.A., \& Goodman, R.S. 1986. Compliance and performance: Toward a contingency theory. In J.E. Post \& L.E. Preston (Eds.), Research in Corporate Social Performance and Policy, 8: 193-221. Greenwich, CT: JAI Press.

Marcus, A.A., \& Weber, M.J. 1989. Externally induced innovation. In A.H. Van de Ven, H.L. Angle, \& M.S. Poole (Eds.), Research on the management of innovation: The Minnesota studies: 537-559. New York: Harper \& Row.

McKinley, W. 1987. Complexity and administrative intensity: The case of declining organizations. Administrative Science Quarterly, 32: 87-105.

Meredith, J.R. 1987. The strategic advantages of the factory of the future. California Management Review, 29(3): 27-41.

Meyer, A.D. 1982. Adapting to environmental jolts. Administrative Science Quarterly, 27: 515-537.

Miller, D. 1987. The Structural And Environmental Correlates Of Business Strategy. Strategic Management Journal, 8, 55-76.

Miller, D., \& Friesen, P.H. 1984. Organizations: A Quantum View. Englewood Cliffs, N.J.: Prentice-Hall.

Mone, M.A., McKinley, W., \& Barker III, V.L. 1997. Organizational decline and innovation: A contingency framework. Working paper, University of Wisconsin-Milwaukee, Milwaukee, WI.

Nemetz, P.L., \& Fry, L.W. 1988. Flexible manufacturing organizations: Implications for strategy formulation and organization design. Academy of Management Review, 13: 627638.

Pitts, R.A., \& Lei, D. 1996. Strategic management: Building and sustaining competitive advantage. St. Paul, MN: West Publishing.

Porter, M.E. 1991. America's green strategy. Scientific American (April): 168.

Portney, P.R. 1990. Air pollution policy. In P.R. Portney (Ed.), Public policies for environmental protection: 27-96. Washington, DC: Resources for the Future.

Sánchez, C.M. 1995. Environmental regulatory impact and firm-level innovation: A study of electric utilities' responses to the Clean Air Act Amendments of 1990. Unpublished doctoral dissertation. Carbondale, IL: Southern Illinois University. 
Sánchez, C.M., \& McKinley, W. 1995. The effect of product regulation on business global competitiveness: A contingency approach. Management International Review, 35: 293305.

Scherer, F.M., \& Ross, D. 1990. Industrial market structure and economic performance. Boston: Houghton Mifflin.

Schon, D.A. 1971. Beyond the stable state. New York: Norton.

Schoonhoven, C.B. 1981. Problems with contingency theory: Testing assumptions hidden within the language of contingency "theory". Administrative Science Quarterly, 26: 4977.

Schoonhoven, C.B., Eisenhardt, K.M., \& Lyman, K. 1990. Speeding products to market: Waiting time to first product introduction in new firms. Administrative Science Quarterly, 35: 177-207.

Shaffer, B. 1994. Regulation, competition, and strategy: Evidence from the auto industry. Business \& Society, 33: 224-225.

Skinner, W. 1986. The productivity paradox. Harvard Business Review (July-August): 5560 .

Smith, A.D., \& Zeithaml, C. 1996. Garbage cans and advancing hypercompetition: The creation and exploitation of new capabilities and strategic flexibility in two regional Bell operating companies. Organization Science, 7: 388-399.

Stinchcombe, A.L. 1965. Social structure and organizations. In J.G. March (Ed.), Handbook of Organizations: 142-193. Chicago: Rand McNally.

Teece, D.J. (Ed.) 1987. The competitive challenge: Strategies for industrial innovation and renewal. Cambridge, MA: Ballinger.

Tushman, M.L., \& Anderson, P. 1986. Technological discontinuities and organizational environments. Administrative Science Quarterly, 1986: 439-465.

Tyre, M.J., \& Orlikowski, W.J. 1994. Windows of opportunity: Temporal patterns of technological adaptation in organizations. Organization Science, 5: 98-118.

Upton, D.M. 1995. What really makes factories flexible? Harvard Business Review (JulyAugust): 74-84. 
U.S. Small Business Administration. 1975. The impact on small business concerns of government regulations that force technological change. Washington, DC: Charleswater Associates, Inc.

Utterback, J.M., \& Abernathy, W.J. 1975. A dynamic model of process and product innovation. Omega, 3: 639-656.

Van de Ven, A.H. 1986. Central problems in the management of innovation. Management Science, 32: 590-607.

Volberda, H.W. 1996. Toward the flexible form: How to remain vital in hypercompetitive environments. Organization Science, 7: 359-374.

Weber, J. 1993. Quick, save the ozone. Business Week, May 17: 78-79.

Westman, W.E. 1985. Ecology, impact assessment, and environmental planning. New York: Wiley.

Wheelwright, S.C. 1987. Restoring the competitive edge in U.S. manufacturing. In D.J. Teece (Ed.), The competitive challenge: Strategies for industrial innovation and renewal: 83100. Cambridge, MA: Ballinger.

Whetten, D.A. 1980. Organizational decline: A neglected topic in organizational science. Academy of Management Review, 5: 577-588.

Yandle, B. 1989. The political limits of environmental regulation. New York: Quorum Books.

Yeoh, P-L. 1995. Do government regulations hurt new product introductions? The case of drug lags in the U.S. pharmaceutical industry. Center for International Business Education and Research Working Paper Series, D-95-13. Columbia, SC: University of South Carolina.

Young, J.H. 1982. Public policy and drug innovations. American Institute History of Pharmacy, 24: 1-56. 